ҚАЗАҚСТАН РЕСПУБЛИКАСЫ

ҰЛТТЫҚ ҒЫЛЫМ АКАДЕМИЯСЫНЫН

АБАЙ АТЫНДАҒЫ ҚАЗАҚ ҰЛТТЫҚ

ПЕДАГОГИКАЛЫҚ УНИВЕРСИТЕТІНІҢ

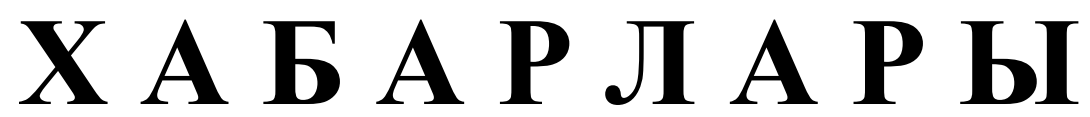

\section{ИЗВЕСТИЯ}

НАЦИОНАЛЬНОЙ АКАДЕМИИ НАУК РЕСПУБЛИКИ КАЗАХСТАН

КАЗАХСКИЙ НАЦИОНАЛЬНЫЙ

ПЕДАГОГИЧЕСКИЙ УНИВЕРСИТЕТ ИМ. АБАЯ

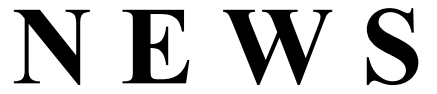

OF THE NATIONAL ACADEMY OF SCIENCES OF THE REPUBLIC OF KAZAKHSTAN

ABAY KAZAKH NATIONAL PEDAGOGICAL UNIVERSITY

ҚОҒАМДЫҚ ЖӘНЕ ГУМАНИТАРЛЫҚ ҒЫЛЫМДАР СЕРИЯСЫ

СЕРИЯ ОБЩЕСТВЕННЫХ И ГУМАНИТАРНЫХ НАУК

SERIES OF SOCIAL AND HUMAN SCIENCES

\author{
6 (322) \\ ҚАРАША - ЖЕЛТОҚСАН 2018 ж. \\ НОЯБРЬ - ДЕКАБРЬ 2018 Г. \\ NOVEMBER - DECEMBER 2018 \\ ИЗДАЕТСЯ С ЯНВАРЯ 1962 ГОДА \\ PUBLISHED SINCE JANUARY 1962 \\ ЖЫЛЫНА 6 РЕТ ШЫҒАДЫ \\ ВЫХОДИТ 6 РАЗ В ГОД \\ PUBLISHED 6 TIMES A YEAR
}

1962 ЖЫЛДЫҢ ҚАНТАР АЙЫНАН ШЫҒА БАСТАҒАН 
Ба с ре дактор

ҚР ҰҒА кұрметті мүшесі

Балықбаев Т.O.

Р е д а ц и я а лқ а сы:

экон. ғ. докторы, проф., ҚР ҰҒА академигі Баймұратов У.Б.; тарих ғ. докторы, проф., ҚР ҰҒА академигі Байпақов К.М.; филос. ғ.докторы, проф., ҚР ҰҒА академигі Есім Г.Е.; фил. ғ. докторы,, проф., ҚР ҰҒА академигі Қирабаев С.С.; эк. ғ. докторы, проф., ҚР ҰҒА академигі Кошанов А.К.; эк.ғ. докторы, проф., ҚР ҰҒА академигі Нәрібаев К.Н. (бас редактордың орынбасары); филос. ғ.докторы, проф., ҚР ҰҒА академигі Нысанбаев А.Н.; заң ғ. докторы, проф., ҚР ҰҒА академигі Сәбікенов С.Н.; заң ғ. докторы, проф., ҚР ҰҒА академигі Сүлейменов М.К.; эк. ғ. докторы, проф., ҚР ҰҒА академигі Сатыбалдин С.С.; тарих ғ. докторы, проф., ҚР ҰҒА академик Әбжанов Х.М.; тарих ғ. докторы, проф., ҚР ҰҒА корр. мүшесі Әбусеитова М.Х.; тарих ғ. докторы, проф., ҚР ҰҒА академик Байтанаев Б.А.; филол. ғ. докторы, проф., ҚР ҰҒА корр. мүшесі Жақып Б.А.; фил. ғ. докторы, проф., академик НАН РК Қалижанов У.К.; филол. ғ. докторы, проф., ҚР ҰҒА академик Қамзабекұлы Д.; тарих ғ. докторы, проф., ҚР ҰҒА академик Қожамжарова Д.П.; тарих ғ. докторы, проф., ҚР ҰҒА академик Койгелдиев М.К.; фил. ғ. докторы, проф., ҚР ҰҒА корр. мүшесі Кұрманбайұлы Ш.; тарих ғ. докторы, проф., ҚР ҰҒА корр. мүшесі Таймағанбетов Ж.К.; социол. ғ. докторы, проф., ҚР ҰҒА корр. мүшесі Шәукенова 3.К.; фил. ғ. докторы, проф., КР ҰҒА корр. мүшесі Дербісәлі А.; саяси. ғ. докторы, проф., Бижанов А.К., тарих ғ. докторы, проф., Кабульдинов 3.Е.; фил. ғ. докторы, проф., ҚР ҰҒА корр мүшесі Қажыбек Е.3.

\section{Р едакция ке н е с i:}

Молдова Республикасының ҰҒА академигі Белостечник Г. (Молдова); Әзірбайжан ҰҒА академигі Велиханлы Н. (Азербайджан); Тәжікстан ҰҒА академигі Назаров Т.Н. (Тәжікстан); Молдова Республикасының ҰҒА академигі Рошка А. (Молдова); Молдова Республикасының ҰҒА академигі Руснак Г. (Молдова); Әзірбайжан ҰҒА корр. мүшесі Мурадов Ш. (Әзірбайжан); Әзірбайжан ҰҒА корр. мүшесі Сафарова 3. (Әзірбайжан); э. ғ. д., проф. Василенко В.Н. (Украина); заң ғ. докт., проф. Устименко В.А. (Украина)

«Қазақстан Республикасы Ұлттық ғылым академиясының Хабарлары. Қоғамдық және гуманитарлық ғылымдар сериясы». ISSN 2224-5294

Меншіктенуші: «Қазақстан Республикасының Ұлттық ғылым академиясы» РҚБ (Алматы қ.)

Қазақстан республикасының Мәдениет пен ақпарат министрлігінің Ақпарат және мұрағат комитетінде 30.04.2010 ж. берілген № 10894-Ж мерзімдік басылым тіркеуіне қойылу туралы куәлік

Мерзімділігі: жылына 6 рет.

Тиражы: 500 дана.

Редакцияның мекенжайы: 050010, Алматы қ., Шевченко көш., 28, 219 бөл., 220, тел.: 272-13-19, 272-13-18, http://nauka-nanrk.kz. social-human.kz

(C) Қазақстан Республикасының Ұлттық ғылым академиясы, 2018

Типографияның мекенжайы: «Аруна» ЖК, Алматы қ., Муратбаева көш., 75. 
Главный редактор

Почетный член НАН РК

T.O. Балыкбаев

Р е дак ци онн а я коллег и я:

докт. экон. Н., проф., академик НАН РК У.Б. Баймуратов; докт. ист. н., проф., академик НАН РК К.М. Байпаков; докт. филос. Н., проф., академик НАН РК Г.Е. Есим; докт. фил. Н., проф., академик НАН РК С.С. Кирабаев; докт. экон. Н., проф., академик НАН РК А.К. Кошанов; докт. экон. Н., проф., академик НАН РК К.Н. Нарибаев (заместитель главного редактора); докт. филос. н., проф., академик НАН РК А.Н. Нысанбаев; докт. юр. Н., проф., академик НАН РК С.Н. Сабикенов; докт. юр. н., проф., академик НАН РК М.К. Сулейменов; докт. экон. Н., проф., академик НАН РК С.С. Сатубалдин; докт. ист. н., проф., академик НАН РК Х.М. Абжанов; докт. ист. н., проф., чл.-корр. НАН РК М.Х. Абусеитова; докт. ист. н., проф., академик НАН РК Б.А. Байтанаев; докт. фил. н., проф., чл.-корр. НАН РК Б.А. Жакып; докт. фиолол. н., проф., академик НАН РК У.К. Калижанов; докт. фил. н., проф., академик НАН РК Д. Камзабекулы; докт. ист. н., проф., академик НАН РК Д.П. Кожамжарова; докт. ист. н., проф., академик НАН РК М.К. Койгельдиев; докт. филол. н., проф., чл.-корр. НАН РК Ш. Курманбайулы; докт. ист. н., проф., чл.корр. НАН РК Ж.К. Таймаганбетов; докт. социол. н., проф., чл.-корр. НАН РК З.К. Шаукенова; д. филол. н., проф., чл.-корр. НАН РК А. Дербисали; доктор политических наук, проф., Бижанов А.К.; доктор ист. наук, проф., Кабульдинов 3.Е.; доктор филол. н., проф., член-корр. НАН РК Қажыбек Е.3.

Р е дак ци онны й с ов ет

академик НАН Республики Молдова Г. Белостечник (Молдова); академик НАН Азербайджанской Республики Н. Велиханлы (Азербайджан); академик НАН Республики Таджикистан Т.Н. Назаров (Таджикистан); академик НАН Республики Молдова А. Рошка (Молдова); академик НАН Республики Молдова Г. Руснак (Молдова); чл.-корр. НАН Азербайджанской Республики Ш. Мурадов (Азербайджан), член-корр. НАН Азербайджанской Республики 3.Сафарова (Азербайджан); д. э. н., проф. В.Н. Василенко (Украина); д.ю.н., проф. В.А. Устименко (Украина)

Известия Национальной академии наук Республики Казахстан. Серия общественных и гуманитарных наук. ISSN 2224-5294

Собственник: РОО «Национальная академия наук Республики Казахстан» (г. Алматы)

Свидетельство о постановке на учет периодического печатного издания в Комитете информации и архивов

Министерства культуры и информации Республики Казахстан № 10894-Ж, выданное 30.04.2010 г.

Периодичность 6 раз в год

Тираж: 500 экземпляров

Адрес редакции: 050010, г. Алматы, ул. Шевченко, 28, ком. 219, 220, тел. 272-13-19, 272-13-18, www:nauka-nanrk.kz / social-human.kz

(C) Национальная академия наук Республики Казахстан, 2018 г.

Адрес типографии: ИП «Аруна», г. Алматы, ул. Муратбаева, 75

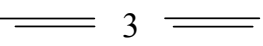


Chief Editor

\section{Honorary member of NAS RK \\ Balykbayev T.O}

Editorial board:

Doctor of economics, prof, academician of NAS RK Baimuratov U.B.; doctor of history, prof, academician of NAS RK Baipakov K.M.; doctor of philosophy, prof, academician of NAS RK Esim G.E.; doctor of philology, prof, academician of NAS RK Kirabayev S.S.; doctor of economics, prof, academician of NAS RK Koshanov A.K.; doctor of economics, prof, academician of NAS RK Naribayev K.N. (deputy editor-in-chief); doctor of philosophy, prof, academician of NAS RK Nyssanbayev A.N.; doctor of law, prof, academician of NAS RK Sabikenov S.N.; doctor of law, prof, academician of NAS RK Suleymenov M.K.; doctor of economy, prof, academician of NAS RK Satybaldin S.S.; doctor of history, prof, academician of NAS RK Abzhanov H.M; doctor of history, prof, corresponding member of NAS RK Abuseitova M.H.; doctor of history, prof, academician of NAS RK Baitanaev B.A.; doctor of philology, prof, corresponding member of NAS RK Zhakyp B.A.; doctor of philology, prof, academician of NAS RK Kalizhanov U.K.; doctor of philology, prof, academician of NAS RK Hamzabekuly D.; doctor of history, prof, academician of NAS RK Kozhamzharova D.P.; doctor of history, prof, academician of NAS RK Koigeldiev M.K.; doctor of philology, prof, corresponding member of NAS RK Kurmanbaiuly Sh.; doctor of history, prof, academician of NAS RK Taimaganbetov J.K.; doctor of sociology, prof, corresponding member of NAS RK Shaukenova Z.K.; doctor of philology, prof, corresponding member of NAS RK Derbisali A.; doctor of political science, prof Bizhanov A.K; doctor of History, prof Kabuldinov Z.E.; doctor of philology, prof, corresponding member of NAS RK Kazhybek E.Z.

\section{Editorial staff:}

Academician NAS Republic of Moldova Belostechnik.G (Moldova); Academician NAS Republic of Azerbaijan Velikhanli N. (Azerbaijan); Academician NAS Republic of Tajikistan Nazarov T.N. (Tajikistan); Academician NAS Republic of Moldova Roshka A. (Moldova) Academician NAS Republic of Moldova Rusnak G. (Moldova); Corresponding member of the NAS Republic of Azerbaijan Muradov Sh. (Azerbaijan); Corresponding member of the NAS Republic of Azerbaijan Safarova Z. (Azerbaijan); Associate professor of Economics Vasilenko V.N. (Ukraine), Associate professor of Law Ustimenko V.A. (Ukraine)

News of the National Academy of Sciences of the Republic of Kazakhstan. Series of Social and Humanities. ISSN 2224-5294

Owner: RPA "National Academy of Sciences of the Republic of Kazakhstan" (Almaty)

The certificate of registration of a periodic printed publication in the Committee of information and archives of the Ministry of culture and information of the Republic of Kazakhstan N 10894-Ж, issued 30.04.2010

Periodicity: 6 times a year

Circulation: 500 copies

Editorial address: 28, Shevchenko str., of. 219, 220, Almaty, 050010, tel. 272-13-19, 272-13-18, www:nauka-nanrk.kz / social-human.kz

(C) National Academy of Sciences of the Republic of Kazakhstan, 2018

Address of printing house: ST "Aruna", 75, Muratbayev str, Almaty 
N E W S

OF THE NATIONAL ACADEMY OF SCIENCES OF THE REPUBLIC OF KAZAKHSTAN

SERIES OF SOCIAL AND HUMAN SCIENCES

ISSN 2224-5294

Volume 6, Number 322 (2018), 124 - 133

https://doi.org/10.32014/2018.2224-5294.44

\author{
G. M. Duysen, D. A. Aitzhanova
}

R.B. Suleimenov Institute of Oriental Studies, Almaty, Kazakhstan

\title{
PROBLEMS AND FEATURES OF THE DEVELOPMENT OF MIGRATION PROCESSES IN KAZAKHSTAN AND CENTRAL ASIA
}

\begin{abstract}
In this paperwork there are examined main problems of the migration policy of Kazakhstan and the countries of Central Asia. The imperfection of the national migration strategy has been noted. The analysis of migration problems of the country is carried out. The opportunities and prospects for improving the state policy in the migration sphere are identified, taking into account the main factors of the country's economic, social and demographic development, foreign policy, integration processes. Kazakhstan's accession to the number of 30 developed countries of the world requires the need to take into account the internal and external challenges of our time, having a direct impact. The authors outlined the main priorities, mechanisms and directions for the long-term development of migration policy. The indicated need for develop active migration projections and realistic scenarios of future socio-economic development in each country / region, taking into account migration factors.

Key words: migration, migration policy, migrants, Central Asia, international labor migration, migration balance, labor market.

The solution of migration problems as an important component of the external and internal policies of Kazakhstan is one of the priorities of the state. The concept of migration policy of the Republic of Kazakhstan represents a system of basic principles, priorities, mechanisms, objectives and methods for streamlining and regulating migration processes. The latter characterizes the complex of administrative and socio-economic measures to stimulate / limit the movement of people, taking into account the current and future needs of Kazakhstan and respect for the rights of migrants. In response to internal and external challenges in the field of migration in the republic, the Concept of the migration policy of the Republic of Kazakhstan for 2017-2021 was approved [1], the main areas of which are focused on:

1) the formation of a new migration policy in order to attract foreign workers to certain sectors of the economy or priority projects in the framework of temporary migration;

2) attracting qualified foreign workers to long-term projects to introduce new innovations, increase entrepreneurship and develop human capital;

3) the implementation of a nationwide program of staff development.

These areas of the national migration policy strategy are interdependent and - permeable and, on this basis, will be implemented in parallel, ensuring the consistency of the country's migration policy.

Migration processes affect state security, public consent, the economic and demographic situation in the country. Millions of people participate in migration processes in the regions of the world. The quantitative growth of migration flows is presented in Fig. 1.

Migration processes and phenomena cover almost all regions and territorial formations of the world community and are carried out between the places of residence of people of different levels and status, as well as numbers. The content of international labor migration (ILM) at the global level includes the following factors:
\end{abstract}


- the movement of labor resources - the global labor market - the development of world production the growth of the global total product;

- involvement of labor resources in social production (reduction of unemployment); - the formation of "migrant sectors" of the economy;

- the introduction of migrants to the world production culture, advanced technologies, more rational organization of labor;

- the development of trade relations between countries;

- cultural exchange between countries (culture, traditions, cuisine, religion), for example, the spread of Islam in Europe (1960-1970s), the fascination with Buddhism in Europe and the USA (1980-1990s), and etc.

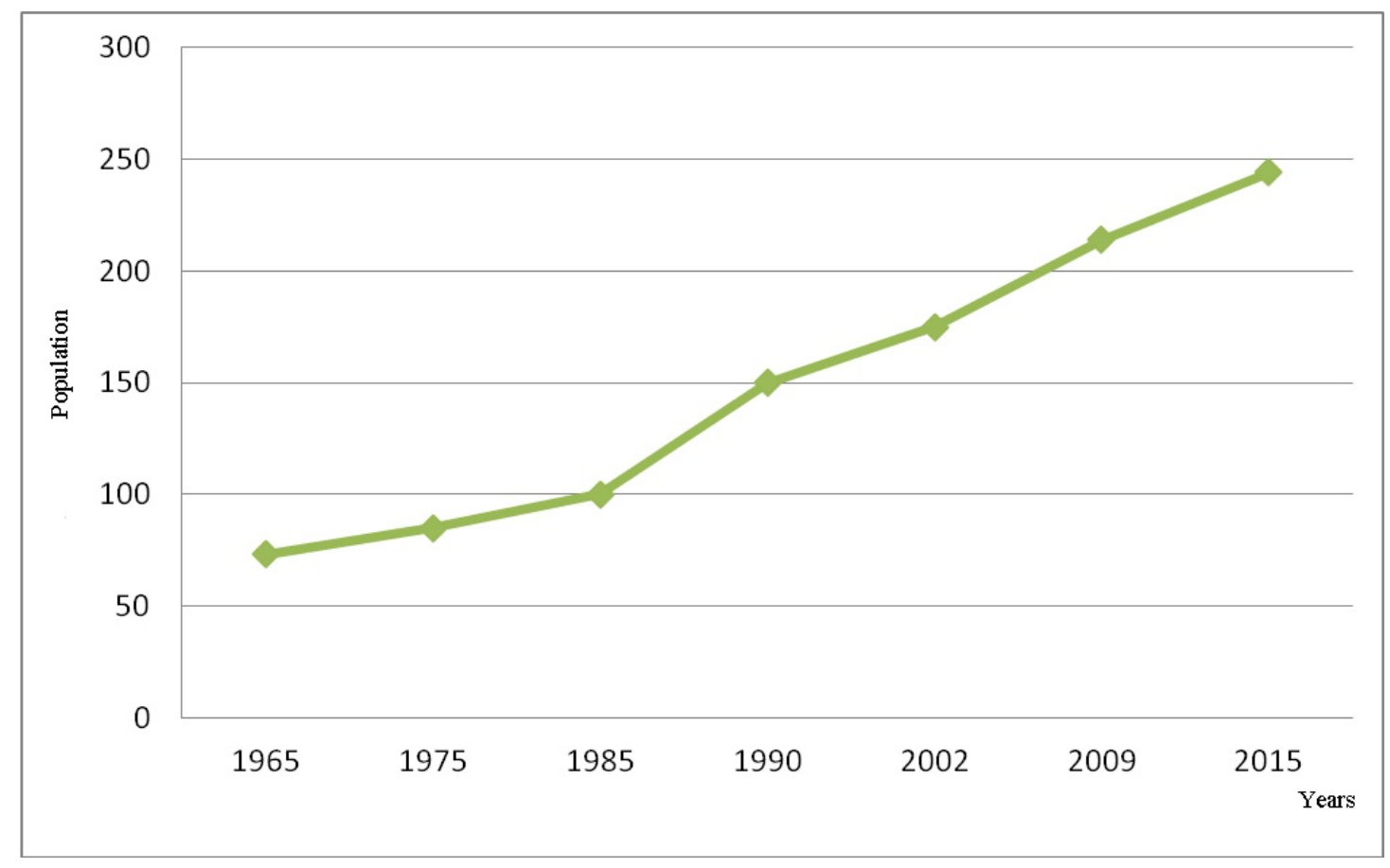

Fig. 1 - Dynamics of migration flows in the world Developed by the authors

Below is the ILM value at the national level (Table 1):

Table 1 - ILM value for the country of entry and country of departure

\begin{tabular}{|c|c|}
\hline \multicolumn{2}{|c|}{ ILM value for: } \\
\hline country of arrival & countries of departure \\
\hline employment & Labor market \\
\hline Unemployment & Transfer of innovation and best practices \\
\hline Wage & Brain drain \\
\hline Price level & Money transfers \\
\hline Social costs for migrants & Demographic factor \\
\hline
\end{tabular}

Compiled by the authors

Migration affects political, social, economic, demographic, and other factors of the development of the state in general and individual regions in particular (Fig. 2): 


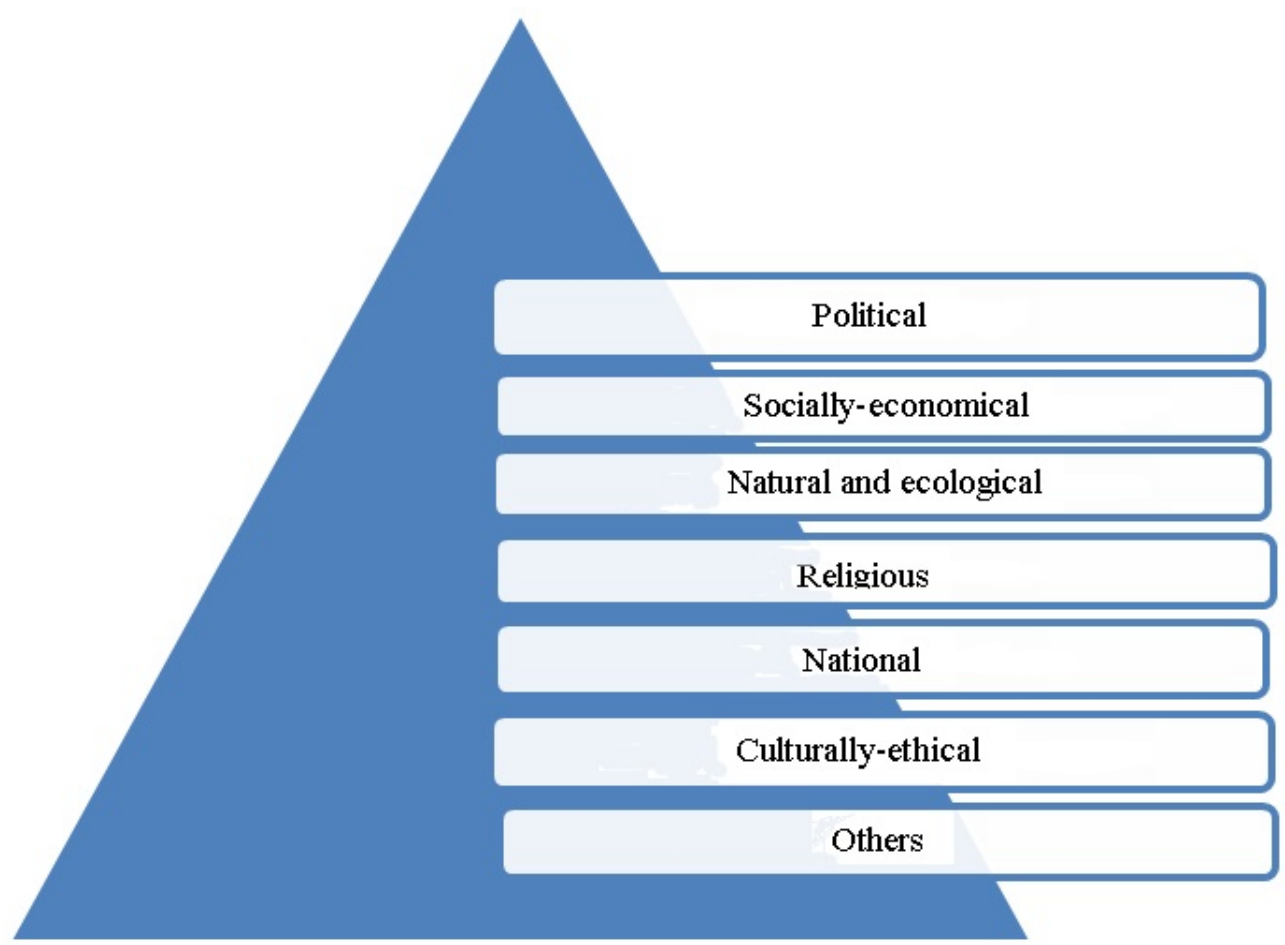

Developed by the authors

Fig. 2 - The main factors the impact of migration on the socio-economic develop and term country

In general, the characteristics of migration situation in Kaz. Rep. can be represented as follows:

Emigration - the prevalence departure of the Russian-speaking part of the population which were exiled during stardom, and who were deported during the years of the Stalin regime and directed towards the development of virgin and fallow lands.

Immigration - is dominated by the influx of ethnic Kazakhs because of: the desire to preserve their national identity; the consequences of military conflicts; desire to return to their historic homeland.

Internal migration - the outflow of population from rural settlements as a result of the decline of the agricultural sector; departure of people from small and medium-sized cities due to the stopping of city-forming enterprises and processing complexes; environmental reasons from the area of the SNTS, Aral and other regions of the country.

Illegal migration - is caused by the geopolitical location of Kazakhstan, the transparency of borders with the CIS countries, the lack of a unified coordinated policy of the countries of the commonwealth and the imperfection of the legal framework.

Labor migration - is associated with the attracting of foreign labor with an existing excess of its own labor resources in the domestic labor market.

The influx of refugees - caused by the unstable socio-political situation in several countries

External labor migration focuses on attracting qualified personnel, reducing the number of unregistered migrant workers and protecting the national labor market.

However, in this area there is a wide range of problems caused by the exacerbation of political, social, climatic environmental and other factors that have a special impact on migration processes. Migration issues are important and relevant for Kazakhstan and Central Asian countries [2]. Characteristics of the external migration of the Republic of Kazakhstan are given in Table. 1: 
Table 1 - Main indicators in External Expansion she RK migration

\begin{tabular}{|l|c|c|c|c|c|c|c|c|}
\hline 2009 & 2010 & 2011 & 2012 & 2013 & 2014 & 2015 & 2016 \\
\hline Immigrants & 42057 & 38016 & 28296 & 24105 & 16784 & 16581 & 13755 \\
\hline 41511 & 26541 & 32920 & 29725 & 24384 & 28946 & 30047 & 34900 \\
\hline Emigrants & & & & \\
\hline 33985 & 15516 & 5096 & -1429 & -279 & -12162 & -13466 & -21145 \\
\hline Migration balance
\end{tabular}

Compiled from data [3]: Demographic Yearbook of Kazakhstan. Statistical collection. Committee on Statistics of the Ministry of National Economy of the Republic of Kazakhstan. - Astana, 2017. - 390 p.

As follows from the table. 1, the migration balance has a steady upward trend.

The overwhelming majority of labor migrants in Kazakhstan from Central Asia come from Uzbekistan and Kyrgyzstan (moreover, China and Turkey are the countries of origin of unregulated labor migrants, of whom migrants make up a rather large percentage of migrants. Unemployment and low living standards force people to migrate [4]. , for example, the official unemployment rate in Kyrgyzstan in 2017 was $2.5 \%$.

The educational level of Kyrgyz and Uzbek migration, in contrast to Turkish and Chinese, is much lower. This explains the specifics of migrant employment: $81.3 \%$ of Kyrgyz are engaged in trade, $49.1 \%$ of Uzbeks are in construction, and Tajiks are in the household sector. In tab. 2 presents data on ethnic migration of the population:

Table 2 - Population migration by ethnic groups in the Republic of Kazakhstan , pers.

\begin{tabular}{|c|c|c|c|c|c|c|c|c|}
\hline & 2009 & 2010 & 2011 & 2012 & 2013 & 2014 & 2015 & 2016 \\
\hline \multicolumn{9}{|l|}{ Moved out } \\
\hline Total & 398640 & 392578 & 397558 & 367566 & 361651 & 434562 & 485498 & 651794 \\
\hline Kazakhs & 298626 & 300673 & 301029 & 277973 & 277148 & 334529 & 375251 & 523480 \\
\hline Russians & 63886 & 57643 & 62229 & 58098 & 54338 & 62718 & 68923 & 78382 \\
\hline Uzbeks & 1822 & 2429 & 2032 & 2572 & 1942 & 3800 & 3833 & 5390 \\
\hline Ukrainians & 8246 & 6907 & 7398 & 6506 & 6241 & 7018 & 7536 & 8202 \\
\hline Uigurs & 3255 & 3201 & 3627 & 2745 & 2614 & 3514 & 4532 & 5732 \\
\hline Tatars & 4102 & 3829 & 3900 & 3524 & 3495 & 3898 & 4456 & 5149 \\
\hline Germans & 5522 & 4714 & 4829 & 4558 & 4536 & 5580 & 6151 & 7067 \\
\hline $\begin{array}{ll}\text { Other } & \text { ethnical } \\
\text { groups }\end{array}$ & 13181 & 13182 & 12514 & 11590 & 11337 & 13505 & 14816 & 18392 \\
\hline
\end{tabular}

Compiled from data [3]: Demographic Yearbook of Kazakhstan. Statistical collection. Committee on Statistics of the Ministry of National Economy of the Republic of Kazakhstan. - Astana, 2017. - 390 p.

According to the table. 2 the maximum number of retired people are Kazakhs (523480 people), the smallest - Tatars (5149 people).

The migration movement in a positive sense needs to be improved, and therefore it is necessary to link it with the solution of social and economic problems, in particular, increasing employment, reducing unemployment and, ultimately, solving problems of economic growth in the country and regions. Given the low population density of Kazakhstan and the active economic policy of the state, the achievement of these goals is impossible without attracting foreign labor. Tab. 3 characterizes data on the number of arriving foreign workers from the CIS and other countries. 
The volume and size of labor migration are important for solving demographic problems in the Republic of Kazakhstan (natural population growth, as of 2016, was 15.14 per 1,000 people) and providing the employment market with the necessary resources. It also envisages the task of attracting highly qualified specialists to the development of promising sectors of the economy.

Table 3 - The number of foreign workers who arrived from the CIS and other countries of the world in 2016

\begin{tabular}{|l|c|c|c|c|c|}
\hline & Belarus & Kazakhstan & Moldova & Russia & Tajikistan \\
\hline Total, and & 17,844 & 30,876 & 1,052 & 1687317 & 10,218 \\
\hline Arrived from the CIS : & 7,648 & 4,813 & 235 & 1567639 & 166 \\
\hline Azerbaijan & 322 & 280 & 35 & 50,139 & - \\
\hline Armenia & $\ldots$ & 16 & 5 & 51512 & - \\
\hline Belarus & - & 42 & $7-$ & - & - \\
\hline Kazakhstan & $\ldots$ & - & 2 & 426 & 13 \\
\hline Kyrgyzstan & $\ldots$ & 70 & 1 & 1,333 & 54 \\
\hline Moldova & 144 & 39 & - & 65,218 & - \\
\hline Russia & $\ldots$ & 1,324 & 44 & - & 34 \\
\hline Tajikistan & 149 & 251 & 2 & 401,724 & - \\
\hline Turkmenistan & 73 & 20 & 1 & 500 & - \\
\hline Uzbekistan & 612 & 1,564 & - & 879519 & 65 \\
\hline Ukraine & 6,348 & 1,207 & 138 & 167268 & - \\
\hline arrived from other countries of the world & 10196 & 26,063 & 817 & 119,678 & 10,052 \\
\hline From China & 7,549 & 12,699 & 20 & 40487 & 8133 \\
\hline Comp & 10 & & & \\
\hline
\end{tabular}

Compiled by source [5]: Kazakhstan and CIS countries 4/2017. Quarterly magazine. Committee on Statistics of the Ministry of National Economy of the Republic of Kazakhstan. Astana, 2017. 106 p.

According to the tab. 3 the maximum number of migrants are from Tajikistan and Uzbekistan. The positive factors of international labor migration for the host country include:

- reducing the cost of goods-services due to the increased competitiveness of local industry due to lower prices);

- growth of aggregate demand in the consumer market due to migrants;

- growth in revenues to budgetary and extrabudgetary funds from migrant income, taxes and insurance contributions to pension and other funds;

- savings on education and prof. training because labor migrants have the appropriate qualifications.

The main migration trends in the Central Asian region are as follows [6]:

1. The high level of labor migration (up to $27 \%$ of the population of Uzbekistan, $18 \%$ of the population of Tajikistan and $14 \%$ of the population of Kyrgyzstan are labor migrants). More than $50 \%$ are involved in low-skilled labor.

2. Huge problems with human trafficking.

3. Changes in the structure of migration due to political instability.

4. High level of internal migration.

5. Increased environmental migration.

The top 20 Asian countries in the corridors of migrants in 2015 is presented in Fig. 3 [7]: 


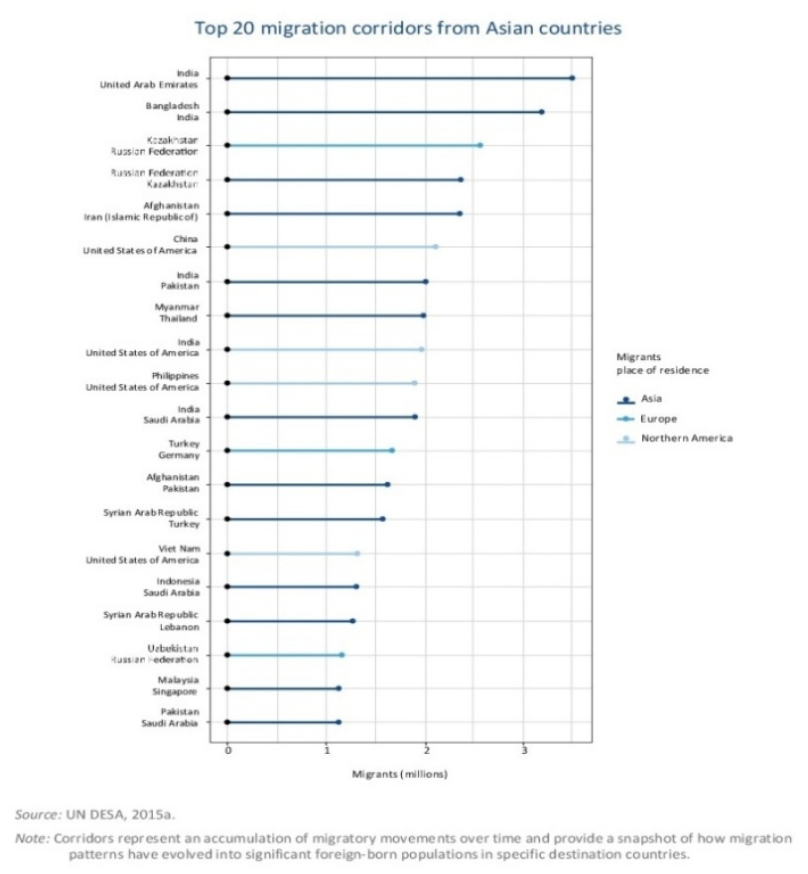

Fig. 3 - Migrant Corridors in Asia

In fig. 4 shows data on migrants from Asia [7]:

Top 20 Asian migrant countries in 2015

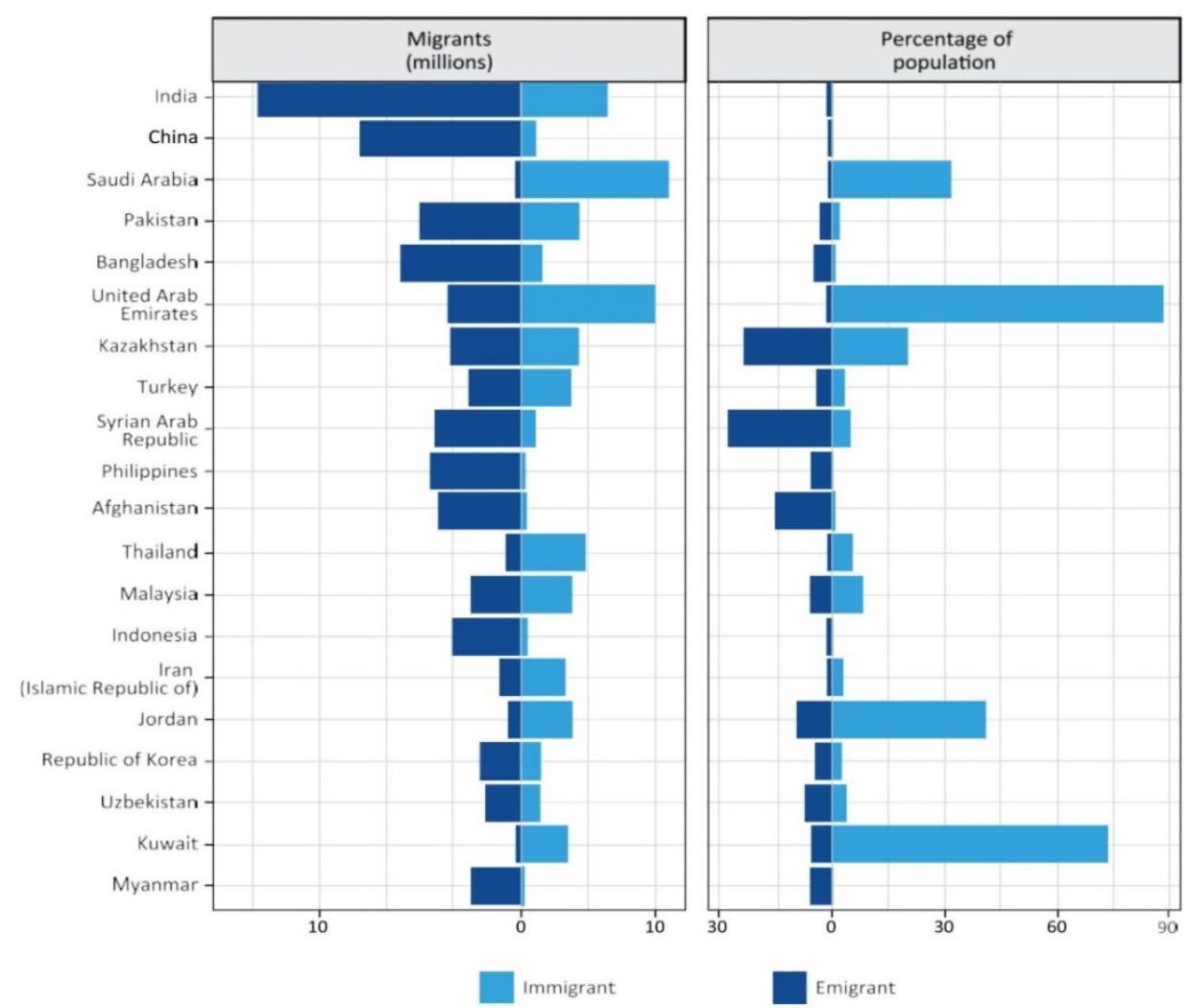

Source: UN DESA, 2015a.

Note 1: The population size used to calculate the percentage of immigrants and emigrants is based on the UN DESA total resident population of the country, which includes foreign-born populations.

Note 2: "Immigrant" refers to foreign-born migrants residing in the country. "Emigrant" refers to people born in the country who were residing outside their country of birth in 2015.

Fig. 4 - The number of migrants from Asia 
The approach to improving the migration policy of the Republic of Kazakhstan, according to our research, can be formulated as follows:

1. In the context of expanding and deepening globalization processes, new approaches are needed to solve problems in migration policy at the country, regional and international levels.

2. Development and improvement of institutions to solve problems of migration nature, reduce social and political tensions in the regions due to the influx of refugees and migrants, as well as prevent regional migration imbalances.

3. On the basis of the current migration situation in the regions, organizational levers are needed to create favorable trends in the development of the migration policy of each country.

4. The governments of each country should include migration factors in their current socio-economic development strategy and medium and long-term perspectives.

5. Migration processes today in the political and economic development of countries and regions are decisive.

6. The solution to migration problems should not be postponed for an indefinite future.

7. From the position of ensuring the national security of countries in specific countries and regions, it is necessary to develop preventive programs and measures to successfully and effectively solve migration problems.

In the end, we are talking about the need to develop active migration forecasts and realistic scenarios for the future socio-economic development in each country / region, taking into account migration factors. In general, the migration policy in the country and regions should proceed not from purely national, but from integral criteria, taking into account the requirements of the politico-socio-ecological-economic equilibrium.

In the migration policy of the Republic of Kazakhstan, the prospects for the economic, social and demographic development of the country, foreign policy, integration processes in the context of global challenges are defined [8]. However, the entry of Kazakhstan among the 30 developed countries of the world requires the need to take into account internal and external calls (Fig. 5):

\begin{tabular}{|c|c|}
\hline External challenges & Internal calls \\
\hline $\begin{array}{l}\text { - the risk of growth of unskilled } \\
\text { labor due to the influx of labor } \\
\text { migrants from the Central Asian } \\
\text { countries; } \\
\quad \text { - the risk of an increase in the } \\
\text { outflow of qualified personnel and } \\
\text { talented youth; } \\
\quad \text { - getting into the country due to } \\
\text { the migration of destructive elements }\end{array}$ & $\begin{array}{l}\text { - an excess of unskilled labor and a shortage of qualified personnel by sector of } \\
\text { the economy; } \\
\text { - overpopulation of large cities and individual territories; } \\
\text { - the formation of centers of social tension due to the high birth rate in the } \\
\text { south of the country, excess labor and resettlement of ethnic migrants in densely } \\
\text { populated regions; } \\
\text { - problems of economic growth and national security of the Republic of } \\
\text { Kazakhstan due to the depopulation of border areas and the reduction of the } \\
\text { population (mostly working age), in northern regions }\end{array}$ \\
\hline
\end{tabular}

The main vectors for improving the migration strategy:

- temporary migration to attract foreign workers to certain sectors of the economy and / or specific priority projects;

- long-term migration in order to attract qualified foreign workers for long-term projects on innovation, business development, human capital development;

- implementation of a nationwide advanced training program

Developed by the authors

Fig. 5 - Improving the migration strategy of the Republic of Kazakhstan

For successful regulation of labor migration, it is necessary to take into account the forecasts of experts, according to which the western, northern, eastern and southern regions of Kazakhstan will receive 
priority development $[9,10]$. For the central region, the preferential development of cities and towns specialized in the mining and processing industries will remain. The able-bodied part of the rural population will move to zones of efficient land use (with higher fertility not less than $60-90$ points of the cadastral valuation of land) and developed infrastructure, creation of new jobs is expected in areas with favorable climatic conditions, and in areas below 50 points cadastral assessments will continue the tendency to curtail agricultural production and outflow of the population. Urbanization processes will be streamlined. About $25 \%$ of the population will live in rural areas.

In general, labor migration policies should proceed from the real needs of the labor market, selective labor migration by granting preferences to highly educated personnel and restricting the flow of unskilled labor migrants $[11,12]$. According to the simplified system of attracting foreign specialists, from January 1, 2017, a rating of necessary specialists was introduced in Kazakhstan based on the country's strategic development goals. Priority is given to candidates with the highest qualifications, the assessment is carried out according to a point estimate, adopted in the United States and Canada.

Assessment of the opportunities and prospects for the development of the migration strategy of the Republic of Kazakhstan determines: 1) identification of priorities of migration problems; 2) determination of mechanisms for their solution; 3 ) designation of the main vectors of the strategy.

The main priorities of the migration policy of the Republic of Kazakhstan are as follows:

- warning and prevention of flows of forced migration, including illegal, and its negative consequences;

- development of the immigration control system in the territory of the Republic of Kazakhstan;

- reduction and stabilization of emigration processes, including prevention of leakage of the intellectual potential of the republic;

- regulation of internal and external labor migration;

- the creation of socio-economic prerequisites and reorientation of migration flows through this;

- the integration of Kazakhstan into the international labor market, encouraging the return of Kazakhstani emigrants, in particular, qualified specialists;

- controllability of immigration processes through the introduction of a unified system of migration control in the territory of Kazakhstan.

Mechanisms for the implementation of migration policy include migration control systems, regulation of labor migration, ensuring state and national security. In order to prevent and combat illegal migration, an integrated approach is based on the following areas:

- creation of an effective system of immigration and immigration control;

- improvement of immigration legislation in terms of protecting the legal rights of migrants and taking measures against foreigners and stateless persons who violated the legislation of the Republic of Kazakhstan;

- creation of temporary accommodation centers for foreigners and stateless persons, as well as their compliance with the rules and regulations of stay in the Republic of Kazakhstan;

- intensification of the treaty process with the CIS countries in the fight against illegal migration;

- creation of conditions for the rapid integration of migrants into the socio-economic life of the Republic of Kazakhstan;

- formation of a migration information center providing registration of foreigners and stateless persons, information on their number, places of location, formation of their diasporas and communities, etc.

Thus, taking into account the above, we can identify the main vectors of the migration strategy of the Republic of Kazakhstan:

1. Linking migration processes with the main directions of the implementation of programs of socioeconomic development of Kazakhstan.

2. Controllability of immigration processes (introduction of unified immigration control; creation of political and socio-economic conditions for fulfilling international obligations to accept migrants; development of programs for using the labor potential of migrants in the interests of the country). 
3. Development of relations with foreign compatriots (facilitating family communication, facilitating border crossing and staying in the territory of the Republic of Kazakhstan; providing preferences for foreign compatriots, for foreigners on access to work and business, study, citizenship and residence permits in Kazakhstan, etc.) [13, 14].

4. Ensuring the rapid integration of migrants into the social environment (coordination of the priorities of migration policy with the state programs of development of the Republic of Kazakhstan; monitoring the socio-economic and environmental situation on the ground, in the labor markets, housing, cultural and everyday life, etc.).

5. Improving laws and regulations in the field of migration policy and control over the entry and exit of foreigners and stateless persons and their stay in the territory of the Republic of Kazakhstan.

6. Development of information and communication technologies (dissemination of knowledge about the history and culture of the peoples of Kazakhstan, motivation, problems, difficulties of adaptation, their national customs and traditions of migrants; ensuring spiritual unity, social and inter-ethnic harmony; dissemination of information about investment projects in migration, etc.).

And the last, according to experts, when implementing the migration concept, target and regional programs for solving migration problems, it is legitimate to use the program-target method. This is important for the development of legal, organizational and economic measures that take into account the multilateral nature of the impact of migration processes on state security, public consent, the economic and demographic situation in the country.

\section{REFERENCES}

[1] Postanovleniye Pravitel'stva Respubliki Kazakhstan ot 29 sentyabrya 2017 g. № 602 O Kontseptsii migratsionnoy politiki Respubliki Kazakhstan na 2017-2021 gody // https://www.zakon.kz/4883114-v-kazahstane-utverzhdena-kontseptsiya.html

[2] Kim G.N. Istoriya immigratsii koreytsev. Kniga vtoraya. 1945-2000 gody. CH. 1. Alma-ty: Dayk-Press, 2006.428 s.

[3] Demograficheskiy yezhegodnik Kazakhstana. Statisticheskiy sbornik. Komitet po stati-stike Ministerstva natsional'noy ekonomiki Respubliki Kazakhstan. Astana, 2017. 390 s.

[4] Tatibekov B.L. Rynok truda i zanyatost' chelovecheskikh resursov Kazakhstana v usloviyakh globalizatsii. - Almaty, 2007. $-264 \mathrm{~s}$.

[5] Kazakhstan i strany SNG 4/2017. Yezhekvartal'nyy zhurnal. Komitet po statistike Mi-nisterstva natsional'noy ekonomiki Respubliki Kazakhstan. Astana, 2017. 106 s.

[6] Voprosy migratsii v Tsentral'noy Azii obsudili vo vremya kruglogo stola v Astane 25.04.2018 // https://kaztrk.kz/ru/news/portal/voprosy-migracii-v-centralnoi-azii-obsudili-vo-vremya-kruglogo-stola-v-astane-112002

[7] The World Migration Report 2018. International Organization for Migration (IOM). Geneva, 2017. 364 p. // http://publications.iom.int/books/world-migration-report-2018

[8] Mel'dakhanova M.K. Chelovecheskiy kapital i ustoychivoye razvitii Kazakhstana: teoriya, prioritety i mekhanizm realizatsii. Almaty. 2011. $464 \mathrm{~s}$.

[9] Mel'dakhanova M.K. Zanyatost' naseleniya i ekonomicheskiy rost: metodologiya, strategiya i mekhanizm regulirovaniya. Almaty. 1999. $296 \mathrm{~s}$.

[10] Migratsii i vosproizvodstvo naseleniya. Nauchnyy doklad. Institut ekonomiki MN-AN RK (Moskvina G.D., Alimbayeva R.N.). Almaty, 1998. $16 \mathrm{s.}$

[11] Khrustalev Ye.YU., Slavyanov A.S. Trudovaya migratsiya i problema innovatsionnogo razvitiya // Problemy prognozirovaniya, 2014, № 1. S. 79-86.

[12] Vorob'yeva O.D., Topilin A.V. Sovremennaya migratsionnaya politika Rossii: illyu-zii i real'nost' // Sotsiologicheskiye issledovaniya, 2016, № 7. S. 134-140.

[13] Adyrbekov I. Etnicheskaya migratsiya: pora menyat' podkhody // Kazakhstanskaya pravda ot 7 noyabrya 2015 g.

[14] Bolat L. Tatibekov, Reuel R. Hanks. Gravity Model of Ethnic Migration and Its Manifesta-tion in Kazakhstan. Kaskelen: Suleyman Demirel University, 2017. 133 p. 
УДК 314.7:574:502.22:614.1:312

\title{
Г.М. Дуйсен, Д.А. Айтжанова
}

Институт востоковедения им. Р.Б. Сулейменова КН МОН РК, г. Алматы, Казахстан

\section{ПРОБЛЕМЫ И ОСОБЕННОСТИ РАЗВИТИЯ МИГРАЦИОННЫХ ПРОЦЕССОВ В КАЗАХСТАНЕ И СТРАНАХ ЦЕНТРАЛЬНОЙ АЗИИ}

\begin{abstract}
Аннотация. В работе рассмотрены основные проблемы миграционной политики Казахстана и стран Центральной Азии. Отмечено несовершенство национальной миграционной стратегии. Проведен анализ миграционных проблем страны. Выявлены возможности и перспективы совершенствования государственной политики в миграционной сфере с учетом основных факторов экономического, социального и демографического развития страны, внешней политики, интеграционных процессов. Вхождение Казахстана в число 30 развитых стран мира требует необходимости учета внутренних и внешних вызовов современности, оказывающих непосредственное воздействие . Авторами обозначены основные приоритеты, механизмы и направления долгосрочного развития миграционной политики. Указана необходимость разработки в каждой стране/регионе активных миграционных прогнозов и реалистических сценариев будущего социальноэкономического развития с учетом миграционных факторов.

Ключевые слова: миграция, миграционная политика, мигранты, Центральная Азия, международная трудовая миграция, сальдо миграции, рынок труда.
\end{abstract}

\section{Г. М. Дүйсен, Д. А. Айтжанова}

\section{КАЗАҚСТАН ЖӘНЕ ОРТАЛЫК АЗИЯ ЕЛДЕРІНДЕГІ КӨШІ-КОН ПРОЦЕССТЕРІ ДАМУЫНЫН МӘСЕЛЕЛЕРІ МЕН ЕРЕКШЕЛІКТЕРІ}

Аннотация. Қазақстан мен Орталық Азия елдерінің көші-қон саясатының негізгі мәселелері қарастырылады. Ұлттық көші-қон стратегиясының жетілмегендігі байқалды. Елдің көші-қон проблемаларын талдау жүргізілуде. Елдің экономикалық, әлеуметтік және демографиялық дамуының, сыртқы саясатының, интеграциялық процестердің негізгі факторларын есепке ала отырып, көші-қон саласындағы мемлекеттік саясатты жетілдірудің мүмкіндіктері мен келешегі анықталды. Қазақстанның әлемнің 30 дамыған елдерінің қатарына кіруі тікелей әсер ететін, біздің уақытымыздың ішкі және сыртқы мәселелерін ескеру қажеттілігін талап етеді. Авторлар көші-қон саясатының ұзақ мерзімді дамуының негізгі басымдықтарын, тетіктері мен бағыттарын белгіледі. Көші-қон факторларын есепке ала отырып, әр елде / аймақта болашақ әлеуметтікэкономикалық дамудың нақты миграциялық болжамдарын және нақты сценарийлерін әзірлеу қажеттілігі көрсетілген.

Түйін сөздер: миграция, миграциялық саясат, мигранттар, Орталық Азия, халықаралық еңбек миграциясы, миграция сальдосы, еңбек нарығы. 


\section{МАЗМҰНЫ}

Беспаева Р.С., Бугубаева Р.О., Мануэль Ф. Грела2. Көрсеткіштердің теңдестірілген жүйесі негізінде Щучинск-Бурабай курорттық аймағын дамытудың кешенді стратегиясын қалыптастыру ................................................................................ 5

Аюпова 3.К., Құсайынов Д.Ө.Азаматтық процесстерді жетілдірудегі интеграцияның кейбір қырлары...................... 13

Құсайынова А. А., Вальдемар Козловски, Геращенко И. П.Қазақстан республикасындағы міндетті әлеуметтік сақтандырудың қаржылық-құқықтық тетіктерінің ерекшеліктері.

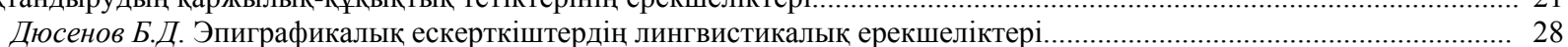

Джумадилова Ш.Г., Атабай Б.Ж. Қазақстандағы халықтың жинақтарының динамикасы......................................... 33

Карабалина А.А., Альситова А. Б., Кереймаганбетова Ж.Н., Абишева Н. М. Құндылық - рухани-адамгершілік

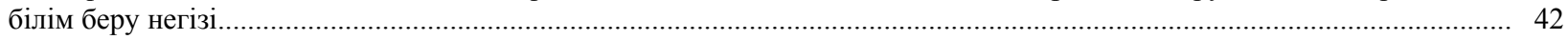

Кенжебаева Д.К., Өрмөрза Б. Ғ., Дашгин Махаммадли. Қазақстандық заманауи жастардың құндылығы............. 51

Нурманова А.Ш., Медерова Д.Е., Дюсенов Б.Д. «Бөкейхан әулетінің талдыбейіт қорымы» эпиграфикалық ескерткіштері тарихи дереккөз ретінде.

Кыдырова Ж.Ш., Онласынов Е.З., Абишова А.У., Шадиева А.А. Оңтүстік Қазақстан облысы сүт және сүт өнімдері нарығындағы жағдайды зерттеу ......

Абимова Г.У., Аманжолов Р., Мынбаева Б.Н., Ибрагимова Д.И. ЖОО-да биолог-студенттердің жобаларды

ұйымдастырылуы мен орындалуына даярлығы.......

Балтабаева А.Ю., Ризаходжаева Г. Мәдени интеграция үдерісіндегі жібек жолының феномені............................... 9

Бурганова Р.И., Абдугалина С.Е., Туякова А.Е. Студенттерге бағытталған білім беру арқылы білім сапасын

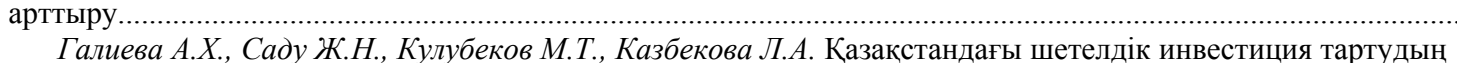

институционалдық жағдайын (талаптарын) бағалау..

Джалилов 3.Г., Батырхан Б.Ш. ХX ғ. екінші жартысындағы шетелдік исламтанушылардың ислам және саясат

туралы теориялық дискурсы.......

Джумабекова А.Т., Канатова А.Ж. Қаржылық ынтымақтастық жағдайларындағы Қазақстан республикасының

ұлттық банкінің өткізу механизмінің өзгеруі......

Дүйсен Г. М., Айтжанова Д. А. Қазақстан және Орталық Азия елдеріндегі көші-қон процесстері дамуының мәселелері мен ерекшеліктері

Есендұлова М.Н. Қазақстандағы « Қиын балаларды» оңалтудың және әлеуметтендірудің психологиялық ерекшеліктері

Жакишева К.М., Жуманова Д.Т., Мукашева Г.М. Экономиканың аграрлық секторының тұрақты дамуына арналған ауыл шаруашылық кәсіпорындарының қаржылық шарттарын мониторингінің рөлі.....

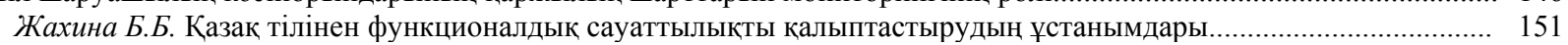

Идресова У.Х., Садуахасова 3.Ж., Муханова А.Т. Криминалистика....................................................................... 156

Савельева В. В. Қазақстандағы кредит технологиясын пайдалану және дамуының тарихи және педагогикалық базасы.

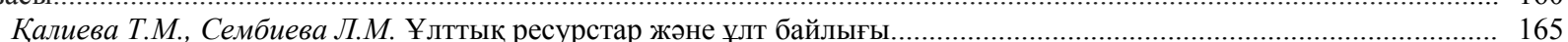

Каримова Р.У., Хаджиева Г.У. ҚХР Ұлттық саясаты контексіндегі ШҰАА-ның этносаяси және әлеуметтікэкономикалық трансформациясы мәселесі.

Керімбек Г., Молдашбаева Л., Джрауова Қ., Ажмухамедова А., Мизанова А. Қазақстан республикасының

республикалық бюджетіне түсетін салық түсімдерінің көрсеткіштерін талдау және бағалау.....

Жолдасбекова С.А., Парманкулова П.Ж., Асаналиев М.К. Мүмкіндігі шектеулі балаларды дамытудағы ұлттық ойындар

Молдакенова Е.К., Байгабулова К.К., Онаева Б.Т. БҚО-да инновациялық үрдістерді басқарудың аймақтық

аспектілігі жүйесінің дамудың жолдары.

Мұратова Г.К., Шаушенова А.Г., Жумасеитова С.Д., Онұварбаева М.Б.Білім беру үрдісінде бұлттық

технологияларын қолдану......

Несіпбеков E. Н., Аппакова Г.Н. Кәсіпорынның инвестициялық портфелін қалыптастырудың теориялық

Нургабылов М.Н., Барлыков Е.К., Егембердиева С.М. ҚР есеп өнеркәсібінің дамуының басқаруының трендсі....... 220

Нурымбетов Т.Я., Абишова А.У., Уразбаева Г.Ж., Кыдырова Ж.Ш., Байнеева П.Т., Абишо Н.У. Модернизациялық

жағдайындағы қр халқын әлеуметтік қолдауының басымдықтары.....

Рахимова С. А., Тургумбекова М. М. Қазақстан республикасындағы шағын және орта бизнестіңмемлекеттік қолдау

бағдарламалары және олардың тиімділігін жүзеге асыру шаралары.......................................................................... 233

Руденко Е.И. Орталық пен Оңтүстік Азия мемлекеттері арасындағы ұғынудың бұрмалануы - «Жұмсақ күш»

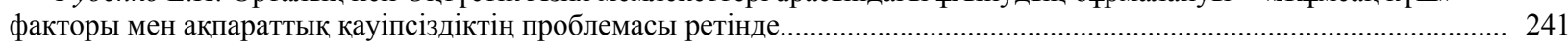

Тохтабаева Ш. Қазына-сандық.......................................................................................................... 251

Утепкалиева К.М., Сабирова Р.К., Кенбаева Г.У. Мұнай-газ секторындағы мемлекеттік-жеке серіктестікті дамыту

Мыңбаев Д. Е. Банкте басқару есебін ұйымдастыру тұжырымдамасы...

Султанова Г.С. Жаңа формацияның экономисі - бакалаврдың кәсіби құзыреттілігін қалыптастырудың

Шаяхметова А.А. Университет жағдайында инклюзивті білім беру үшін педагогтарды оқыту....... 


\section{СОДЕРЖАНИЕ}

Беспаева Р.С., Бугубаев Р.О., Мануэль Ф. Грела. Формирование комплексной стратегии развития ЩучинскоБоровской курортной зоны на основе сбалансированной системы показателей. Аюпова 3.К., Кусаинов Д.У., Уинстон Наган. Некоторые грани интеграции в совершенствовании гражданского процесса.

Кусаинова А.А., Козловски Вальдемар, Геращенко И.П. Обзор некоторых особенностей финансово-правового механизма обязательного социального страхования в республике Казахстан......

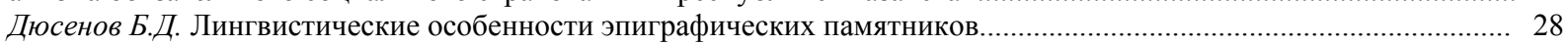

Джумадилова Ш.Г., Атабай Б.Ж.Динамика сбережений населения в Казахстане................................................... 33

Карабалина А.А., Альситова А. Б., Кереймаганбетова Ж.Н., Абишева Н. М. Ценность как базовая основа духовнонравственного образования.

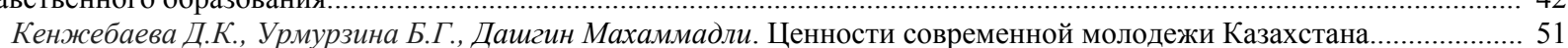

Нурманова А.Ш., Медерова Д.Е., Дюсенов Б.Д. Эпиграфические памятники «Некрополи талдыбейит династии

Бокейхановых» как исторический источник.

Кыдырова Ж.Ш., Онласынов Е.З., Абишова А.У., Шадиева А.А.Исследование ситуации на рынке молока и молочной продукции южно-казахстанской области

Абишова Г.У., Аманжолов Р., Мынбаева Б.Н., Ибрагимова Д.И. Готовность студентов-биологов к организации

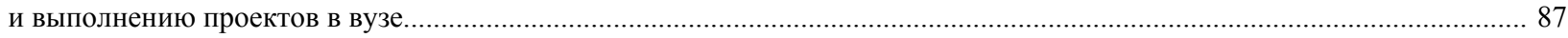

Балтабаева А.Ю., Ризаходжаева Г. Феномен великого шелкового пути в процессе культурной интеграции............... 91

Бурганова Р.И., Абдугалина С.Е., Туякова А.Е. Повышение качества образования посредством

студентоцентрированного обучения...

Галиева А.Х., Саду Ж.Н., Кулубеков М.Т., Казбекова Л.А. Оценка институциональных условий привлечения

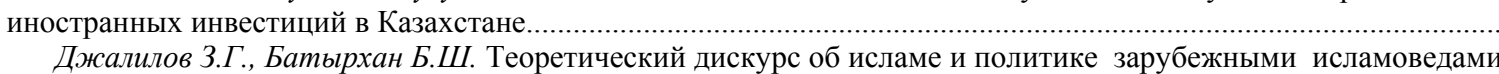
второй половины ХX в.

Джумабекова А.Т., Канатова А.Ж. Трансформация трансмиссионного механизма национального банка республики

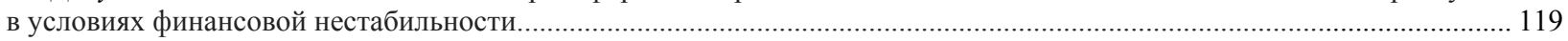

Дуйсен Г.М., Айтжанова Д.А. Проблемы и особенности развития миграционных процессов в Казахстане

и странах Центральной Азии.

Есенгулова М.Н. Психологические особенности реабилитации и социализации "Трудных подростков"

в Казахстане".

Жакишева К.М., Жуманова Д.Т., Мукашева Г.М.Роль мониторинга финансового состояния сельскохозяйственных

предприятий в обеспечении устойчивого развития аграрного сектора экономики.........................................................146

Жахина Б.Б. Принципы формирования функциональной грамотности казахского языка.......................................... 151

Идресова У.Х., Садуахасова 3.Ж., Муханова А.Т. Криминалистика......................................................................... 156

Савельева B.B. Исторические и педагогические основы формирования и разработки кредитной технологии

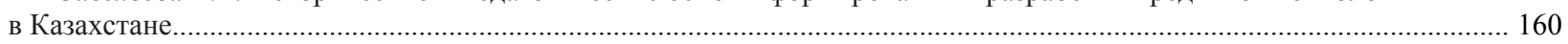

Калиева Т.М., Сембиева Л.М. Национальные ресурсы и богатство нации.................................................. 165

Каримова Р.У., Хаджиева Г.У. К вопросу об этно-политической и социально-экономической трансформации

СУАР в контексте национальной политики КНР

Керимбек Г., Молдашбаева Л., Джрауова Қ., Ажмухамедова А., Мизанова А. Анализ и оценка показателей

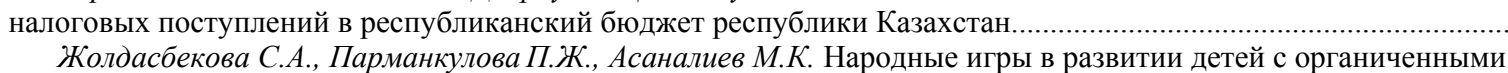

Жолдасбекова С.А., Парманкулова П.Ж., Асаналиев М.К. Народные игры в развитии детей с органиченными

Молдакенова Е.К., Байгабулова К.К., Онаева Б.Т.Пути развития системы регионального аспекта управления

инновационными процессами в АПК.

Муратова Г.К., Шаушенова А.Г., Жумасеитова С.Д., Онгарбаева М.Б. Применение облачных технологий

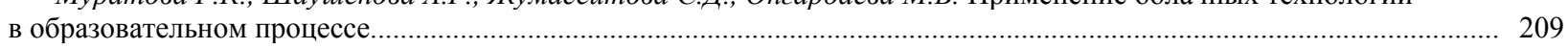

Несипбеков Е.Н., Аппакова Г.Н. Теоретические аспекты формирования инвестиционного портфеля предприятия. 214

Нургабылов М.Н., Барлыков Е.К., Егембердиева С.M. Тенденции управления развитием мясоперерабаты-

вающей отрасли в РК.

Нурымбетов Т.Я., Абишова А.У., Уразбаева Г.Ж., Кыдырова Ж.Ш., Байнеева П.Т., Абишов Н.У. Приоритеты

социальной поддержки населения РК в условиях модернизации................................................................................. 22

Рахимова С. А., Тургумбекова М. М. Программы государственной поддержки мсб в республике Казахстан и меры

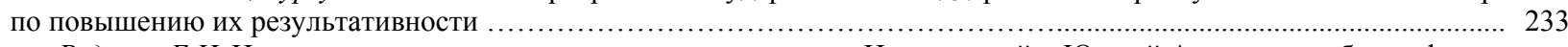

Руденко Е.И. Искаженность восприятия между государствами Центральной и Южной Азии как проблема фактора

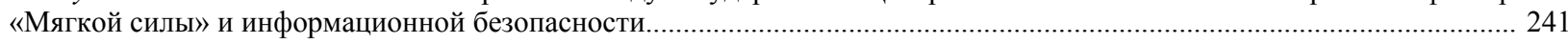

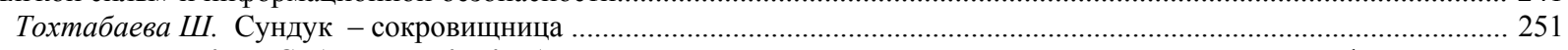

Утепкалиева К.М., Сабирова Р.К., Кенбаева Г.У.Развитие государственно-частного партнерства в нефтегазовой

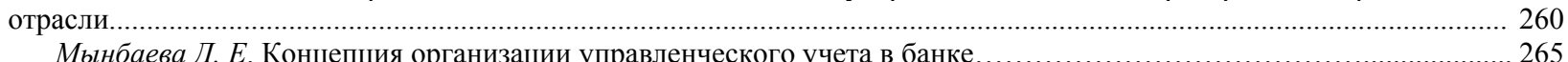

Мынбаева Д. Е. Концепция организации управленческого учета в банке...........................................2.
Султанова Г.С. Педагогические аспекты формирования профессиональных компетенций бакалавра - экономиста

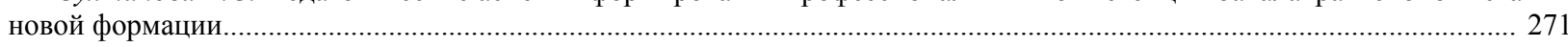

Шаяхметова А.А. О подготовке педагогических кадров к инклюзивному образованию в условиях вуза................ 277 


\section{CONTENTS}

Bespayeva R.S., Bugubayeva R.O., Manuel F. Grela. Formation of the complex strategy for development of the Schuchinsk-

Burabay resort area based on the balanced system of indicators.

Ayupova Z.K., Kussainov D.U., Winston Nagan. Some facets of integration in themodernization ofthe civil process..............13

Kussainova A.A., Kozlowski Waldemar, Gerashchenko I.P. The review of some features of the financial legal mechanism of obligatory social insurance in the republic of Kazakhstan...

Dyussenov B.D. Linguistic features of epigraphic monuments................................................................................ 28

Jumadilova Sh.G., Atabay B.Zh. Dynamics of the population savings in Kazakhstan.......................................................... 33

Karabalina A.A., Alsitova A.B., Kereimaganbetova Zh.N., Abisheva N.M. The values as critical factor of moral education... 42

Kenzhebayeva D.K., Urmurzina B.G., Dashqin Mahammadli. The modern youth values in Kazakhstan............................. 51

Nurmanova A.S., Mederova D.E., Dyussenov B.D. "Bokeykhanov dynasty taldybeyit necropolis" epigraphic monuments

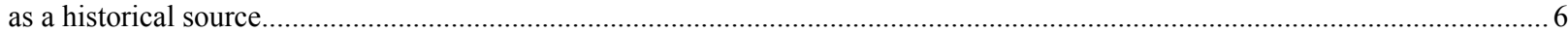

Kydyrova Zh.Sh., Onlasynov E.Z., Abishova A.U., Shadieva A.A.Research of the situation in the market of milk and dairy

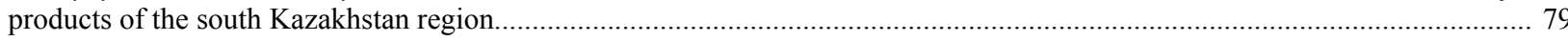

Abishova G.U., Amanzholov R.A., Mynbayeva B.N., Ibragimova D.I. Readiness of students-biologists for the organization

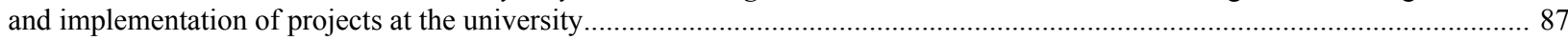

Baltabayeva A.Y., Rizakhojayeva $G$. The phenomenon of the great silk road in the cultural integration process................... 91

Burganova R.I., Abdugalina S.E., Tuyakova A.E. Improving the quality of education through student-centered education... 102

Galiyeva A.Kh., Sadu Zh.N., Kulubekov M.T., Kazbekova L.A. Assessment of the institutional terms of the foreign

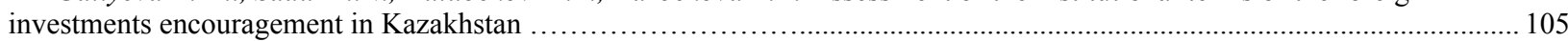

Dzhalilov Z.G. Theoretical discourse on islam and politics in foreign humanism of the second half of 20th century.......... 112

Dzhumabekova A.T., Kanatova A.ZH. Transformation of the transmission mechanism of the national bank of the republic

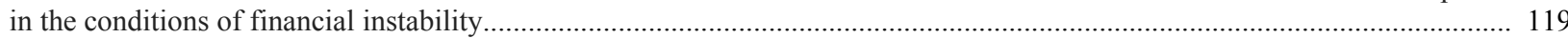

Suleimenov R.B. Problems and features of the development of migration processes in Kazakhstan and Central Asia.......... 124

Yesengulova M.N. Psychological aspects of reintegration and resocialization of "Trouble" adolescents in Kazakhstan....... 134

Zhakisheva K.M., Zhumanova D.T., Mukasheva G.M.The role of monitoring the financial condition of agricultural

enterprises in ensuring sustainable development of the agrarian sector of the economy......................................................... 146

Zhakhina B.B. Principles of functional literacy formation of the kazakh language....................................................... 151

Idresova U.Kh., Saduahasova Z.Zh., Mukhanova A.T. Criminalistics............................................................................. 156

Savelyeva $V . V$. Historicalandpedagogical bases of formation and development of credit technology in Kazakhstan........... 160

Kaliyeva T.M., Sembiyeva L.M. National Resources and national wealth.................................................................. 165

Karimova R., Hajiyeva G. Examining ethno-political and SOCIO-economic transformation of the xinjiang uyghur

autonomous region in the context of the PRC national policies........................................................................................ 176

Kerimbek G., Moldashbayeva L., Jrauova K., Azhmukhamedova A., Misanova A. Analysis and evaluation of reduction

of tax recovery of the republic of kazakhstan on the budget of the republic of Kazakhstan................................................. 185

Zholdasbekova S.A., Parmankulova P.Zh., Assanaliyev M.K. Folk games in the education of children with physical, mental and sensory disturbances..

Moldakenova E.K., Baygabulova K.K., Onaeva B.T. Ways of development of the system of the regional aspect of managing innovative processes in the APC.

Muratova G.K., Shaushenova A.G., Zhumassseitova C.D., Ongarbayeva M.B. Application of cloud technologies in the educational process......

Nurgabylov M.N., Barlikov E.K., Egemberdieva S.M. Trends of management of the development of meat processing industry in RK

Nurymbetov T.Ya., Abishova A.U., Urazbaeva G.Zh., Kydyrova Z.Sh., Baineeva P.T., Abishov N.U. Priorities of social support of the population of republic of Kazakhstan in the conditions of modernization........

Rakhimova S. A., Turgumbekova M. M. Programs of government support for sme in the republic of Kazakhstan and measures to enhance their efficiency.....

Rudenko Ye.I. Misperception between the states of Central and South Asia as a 'Soft power' and information security issue...

Tokhtabayeva Sh. Zh. Treasure-chest.

Utepkalieva K.M., Sabirova R.K., Kenbaeva G.U.Development of public private partnership approach in oil and gas

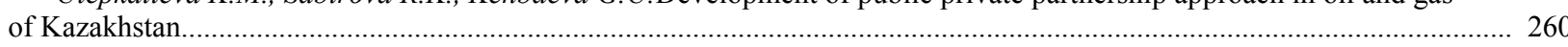

Mynbayeva D.E. Concept of organization of management accounting in bank ........................................................... 265

Sultanova G. S. Pedagogical aspects of formation of professional competence of the bachelor-economist of the new formation

Shayakhmetova A.A. On the training of teaching staff for inclusive education under the conditions of higher education institution. 


\section{PUBLICATION ETHICS AND PUBLICATION MALPRACTICE IN THE JOURNALS OF THE NATIONAL ACADEMY OF SCIENCES OF THE REPUBLIC OF KAZAKHSTAN}

For information on Ethics in publishing and Ethical guidelines for journal publication see http://www.elsevier.com/publishingethics and http://www.elsevier.com/journal-authors/ethics.

Submission of an article to the National Academy of Sciences of the Republic of Kazakhstan implies that the work described has not been published previously (except in the form of an abstract or as part of a published lecture or academic thesis or as an electronic preprint, see $\mathrm{http} / / / \mathrm{www} . e l s e v i e r . c o m / p o s t i n g p o l i c y)$, that it is not under consideration for publication elsewhere, that its publication is approved by all authors and tacitly or explicitly by the responsible authorities where the work was carried out, and that, if accepted, it will not be published elsewhere in the same form, in English or in any other language, including electronically without the written consent of the copyrightholder. In particular, translations into English of papers already published in another language are not accepted.

No other forms of scientific misconduct are allowed, such as plagiarism, falsification, fraudulent data, incorrect interpretation of other works, incorrect citations, etc. The National Academy of Sciences of the Republic of Kazakhstan follows the Code of Conduct of the Committee on Publication Ethics (COPE), and follows the COPE Flowcharts for Resolving Cases of Suspected Misconduct (http://publicationethics.org/files/u2/New_Code.pdf). To verify originality, your article may be checked by the originality detection service Cross Check http://www.elsevier.com/editors/plagdetect.

The authors are obliged to participate in peer review process and be ready to provide corrections, clarifications, retractions and apologies when needed. All authors of a paper should have significantly contributed to the research.

The reviewers should provide objective judgments and should point out relevant published works which are not yet cited. Reviewed articles should be treated confidentially. The reviewers will be chosen in such a way that there is no conflict of interests with respect to the research, the authors and/or the research funders.

The editors have complete responsibility and authority to reject or accept a paper, and they will only accept a paper when reasonably certain. They will preserve anonymity of reviewers and promote publication of corrections, clarifications, retractions and apologies when needed. The acceptance of a paper automatically implies the copyright transfer to the National Academy of sciences of the Republic of Kazakhstan.

The Editorial Board of the National Academy of sciences of the Republic of Kazakhstan will monitor and safeguard publishing ethics. 
Правила оформления статьи для публикации в журнале смотреть на сайте:

\section{www:nauka-nanrk.kz}

\section{social-human.kz}

Редакторы М.С. Ахметова, Т.А. Апендиев, Д.С. Аленов

Верстка на компьютере А.М. Кульгинбаевой

Подписано в печать 08.12.2018

Формат 60x881/8. Бумага офсетная. Печать - ризограф.

17,7 п.л. Тираж 500. Заказ 6.

Национальная академия наук $Р К$

050010, Алматы, ул. Шевченко, 28, т. 272-13-18, 272-13-19 